\title{
EARNINGS MANAGEMENT AND ECONOMIC VALUE ADDED IN CHINA, AFRICAN AND LATIN- AMERICAN MARKETS: A STUDY OF LOGISTICS MODEL, SUPPORT VECTOR MACHINES AND ROUGH SET THEORY
}

DOI: $10.17261 /$ Pressacademia.2018.939

JEFA- V.5-ISS.3-2018(8)-p.305-320

\section{Zhen-Jia-Liu}

Changzhou University, School of Business, Changzhou City, Jiangsu Providence, China. 2240328588@qq.com

Date Received: July 4, 2018

Date Accepted: September 14, 2018

\section{To cite this document}

Liu, Z. J. (2018). Earnings management and economic value added in China, African and Latin-American markets: a study of logistics model, support vector machines and rough set theory. Journal of Economics, Finance and Accounting (JEFA), V.5(3), p.305-320.

Permemant link to this document: http://doi.org/10.17261/Pressacademia.2018.939

Copyright: Published by PressAcademia and limited licenced re-use rights only.

\begin{abstract}
Purpose- This study to predict the association between earnings management and EVA, evaluated it for accuracy.

Methodology- This study through logistic regression model (excluding OLS regression model), Support Vector Machines and Rough Set Theory

Findings- Empirical results show that RST model exhibited the highest accuracy in China and Africa nations. SVM model exhibited the highest accuracy in Latin-America nations.

Conclusion- Our results provide critical implications for managers, researchers, investors, and regulators. Managers should analyze whether EVA motivates managers to engage in earnings management behavior. For researchers, we adopted logit, SVM and RST model to predict effect of earnings management on economic value added; For investors, they can analyze the true value of enterprises, regardless of whether enterprises have adopted earnings management. Regulators (e.g., governments) should establish stricter security measures and laws or rules for listed firms to prevent earnings management following a financial tsunami and to encourage them to report their "real" true value.
\end{abstract}

Keywords: Earnings management, economic value added, logistics model, support vector machines, rough set theory. JEL Codes: M40, M41, M49

\section{INTRODUCTION}

Earnings management is managers exercise judgment in financial reporting and in structuring transactions to adjust financial reports, either to mislead stakeholders about the reported accounting numbers of a company (Healy \& Wahlen, 1999). Economic value added (EVA), is used to evaluate economic value, assess funds, and efficiently allocate resources, and it involves using adjustment items to reflect the true economic value of a firm. However, EVA is also based on financial statements for measuring opponents; it is highly probable that EVA motivates managers to engage in earnings management behavior. Wang et al., (2015) and Liu (2016) analyze effect of earnings management on economic value added. However, these results presented only investigate whether earnings management influences a firm's EVA from the perspective of capital cost. In addition, they do not conduct several diagnostic tests (including an accuracy evaluation). Thus, this finding has caused some commentators to question the reliability and comparability of the emerging body of empirical evidence.

Economic value added is the only criterion which calculates the value of the company in real terms and is the fundamental indicator to measure the performance and determining of the value of the company. Investors' concern of the return of principle as well as profit of their investment has led us to forecast status of economic value added as a basis to evaluate companies' performance. Predicting the status of economic value added is one of the ways that can be used to exploit investment opportunities and also to avoid waste of resources (Hajabedi et al, 2016). Methods for economic value added have been extensively researched. Classical statistical techniques influenced the formation of these models such as linear regression (Shiri et al., 2013), Neural Networks (Shiri et al., 2013), Genetic Algorithms (Hajabedi et al, 2016). However, other 
models have not been used directly to forecast the level of economic value added in advance. The main contribution of this study to the literature is that, based on our research, it is the first study to predict the association between earnings management and EVA through logistic regression model, support vector machines and rough set theory, evaluated it for accuracy.

We adopted real earnings management (REM) activities and discretionary accrual (DA) items to measure earnings management, and both unadjusted and adjusted EVA for determining EVA. Because countries have relatively distinct governments, cultures, laws, and economic conditions, enterprises operate in unique systems and environments; hence, they cannot be considered equivalently. International investors paid closer attention to China, Africa (e.g., Egypt, Nigeria, South-Africa, Kenya, Morocco) and Latin-America nations (e.g., Mexico, Brazil, Argentina, Chile, Peru, Colombia) after the 2008 financial tsunami because they were growing. Thus, we have developed logistic regression model (Logit), support vector machines (SVM) and rough set theory (RST), evaluated it for accuracy, and compared in China, Africa and LatinAmerica nations, based on these models.

The remainder of the paper is organized as follows. Section 2 presents a brief review of the related literature. Section 3 provides details of the research design and sample selection procedure and develops our model. Section 4 presents our empirical findings. Section 5 contains a summary and conclusions.

\section{LITERATURE REVIEW}

\subsection{Economic Value Added (EVA)}

EVA is calculated "after subtracting the cost of capital from the operating profits (Stewart, 1991). Manorselvi and Vijayakumar (2007) revealed that the traditional measures of performance do not reflect the real value addition to shareholders wealth and EVA has to be explained shareholders value addition. Destri et al.,(2012) showed that a performance and cost measurement system that integrates the Economic Value Added criteria (EVA) with Process Based Costing (PBC). Zhao and Wang (2012) showed that it is important and practical to replace traditional indicators with EVA indicator in the performance evaluation of commercial banks. Teker et al.,(2011) showed that Economic Valued Added is a recent financial tool that helps to determine the true shareholder wealth contribution of a bank. Hence, EVA results and ranking of banks convey critical information for decision makers. Shil and Das (2012) showed that a discussion of possible changes to corporate strategies and business performance when the integrated ABC (activity based costing) and-EVA system is implemented in a manufacturing company for pricing their products. Chen et al., (2014) showed that the improved EVA-ABC (Activity based Costing) based DuPont analysis system can reduce the negative impacts of accounting principles and objectively reflect the operating performance of the enterprise. Wang \& Wang (2016) indicated that EVA can't significantly reduce the listed state-owned corporations' overinvestment, but it has different inhibition effect on different growth corporations. The EVA can significantly reduce low growth listed state-owned corporations' overinvestment, which suggests the EVA evaluation system can improve low growth corporations' investment situation. Saha et al.,(2016) indicated that Malaysian banks step into Basel-III era; a close look at their performance on risk adjusted basis using EVA would throw significant light on their relative strengths and weaknesses. Maitah et al., (2015) indicated that the relationship between economic value added and stock prices, and analyzed the benefit of the use of economic value added in the creating process of investment policies that can be helpful to get extraordinary returns. Victoria \& Kamoche (2016) indicated that there was a positive relationship between profitability and adoption of EVA by the insurance firms in Kenya. They also indicated a high potential for increasing adoption of EVA for performance measurement which should be leveraged on by key industry stakeholders to spearhead expectation of use of EVA to evaluate the performance of specific firms.

Regarding the factors that influence EVA, Chen \& Qiao (2008) indicated that earnings ability (i.e., EPS) and management ability (i.e., account receivable turnover, assets turnover) are significantly positively related to EVA. Martani \& Saputra (2009) showed that corporate governance index, sales growth, leverage, size, and age of the firm are significantly positively related to EVA. Bhasin (2012) showed that return on capital employed, earnings per share are positively related to EVA. Abraham et al., (2017) show that earnings yield significantly explained economic value added. The analysis is conducted both across industries and within the oil and gas, computer software, biotechnology and retail industries.

\subsection{Earnings Management}

In literature, many studies (e.g. Phan et al.,2017; Gleason et al.,2017; Zhou \& Wu,2016; Gras-Gil et al.,2016; Dhole et al.,2016; Hsieh et al.,2016; Campa \& Camacho-Miñano, 2015; Ali \& Zhang,2015; Ifada \& Wulandari,2015; Chen et al.,2015; Liu et al., 2014; Badolato et al.,2014; Datta et al,2013; Alves,2012; Hochberg,2012; Feng et al.,2011; Zang, 2011; Badertscher, 2011; Peni \&Vahamaa,2010; Lin \& Hwang,2010; Liu et al.,2010; Mitani,2010; García-Meca \& Sánchez-Ballesta,2009 ; Banderlipe,2009; Chih et al.,2008; Cohen et al.,2008; Ali et al.,2008; Cornett et al., 2008; Noor et al.,2007; Ding et al.,2007; Davidson et al.,2007; Ebrahim, 2007) related to earnings management only focus on 
identifying some related factors which can significantly affect earnings management. However, these factors have not been used directly to forecast the level of earnings management in advance (Tsai \& Chiou, 2009). In order to help the investors in the stock market, it is necessary to develop a model which is able to predict the level of earnings management. Methods for predicting earnings management have been extensively researched. Classical statistical techniques influenced the formation of these models such as neural networks (Tsai \& Chiou,2009; Hoglund, 2012; Pourhasan \& Mansour,2014; Mahmoudi et al.,2017); decision trees (Tsai \& Chiou,2009); Benford's Law (Lin \& Wu, 2014). data mining (Chen et al.2015). Therefore, determining the strategy and finding tools to predict the level of earning management to use in decision making of financial statements users can be very beneficial.

Previous research has also examined earnings management via consideration of the decomposition of total accruals to their abnormal or discretionary components (e.g., Collins et al.,2017; Phan et al.,2017; Gras-Gil et al.,2016; Dhole et al.,2016; Hsieh et al., 2016; Zhu et al., 2015; Chen et al.,2015; Liu et al.,2014; Datta et al,2013; Dechow et al.,2012; Alves,2012; Zang, 2011; Badertscher, 2011; Peni \& Vahamaa,2010; García-Meca \& SánchezBallesta,2009; Huang et al.,2007; Piot \& Janin,2007). If an accrual model estimates the coefficient within the same industry, it assumes that firms in the same industry have similar accrual-generating processes. However, the uniform accrual-generating process assumption may not be proper for firms with extreme performance within the industry, leading to biased discretionary accrual estimates (Wu, 2014).

Second, managers can manage earnings by real operating decisions ( referred to as real-based earnings management; REM). These actions deviate from normal business practices, with the primary objective of misleading stakeholders on underlying economic performance (Phan et al., 2017; Dhole et al., 2016; Chen et al., 2015; Chen et al., 2012; Zang, 2011; Badertscher, 2011; Mizik, 2010; Bhojraj et al., 2009).

\section{METHODOLOGY}

Using earnings management to predict economic value added, this study collected data from 2009 to 2016 from COMPUSTAT database and corporate website (excluding banking sectors such as banks, securities firms, and insurance firms). Microeconomic variables such as risk free (fixed deposit interest rate in one year) and return of market (portfolio) were used to calculate economic value added in China, Africa and Latin-America nations, incorporating data from the world development indicators (indicators from the World Bank) or stocks exchange. Variables and research model of this research are as follows.

\subsection{Earnings Management}

\subsubsection{Discretionary Accruals (DA)}

DAs represent the component of total accruals that is more susceptible to manipulation by managers, and is has been used frequently in prior studies as a proxy for earnings management, where the absolute value of $\varepsilon_{i t}$ to measure DAs were adopted.

$$
\frac{\text { MACC }_{i t}}{T A_{i t-1}}=\frac{\beta_{o t}}{T A_{i t-1}}+\frac{\beta_{1 t} \Delta N E T R E V_{i t}}{T A_{i t-1}}+\frac{\beta_{2 t} P P E_{i t}}{T A_{i t-1}}+\varepsilon_{i t}
$$

where $M A C C_{i t}$ is the total accruals calculated as the change in non-cash current assets minus the change in current

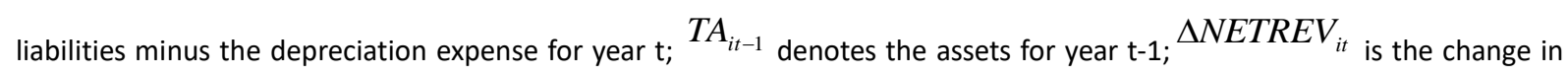
net revenue for year $\mathrm{t}$; and $P P E_{i t}$ is the gross fixed assets for year $\mathrm{t}$. (Jones,1991)

$$
\frac{A C C_{i t}}{T A_{i t-1}}=\frac{\beta_{0}}{T A_{i t-1}}+\beta_{1} \frac{\Delta S A L E S_{i t}-\Delta A R_{i t}}{T A_{i t-1}}+\beta_{2} \frac{P P E_{i t}}{T A_{i t-1}}+\varepsilon_{i t}
$$

where $A C C_{i t}$ represents the total accruals calculated as the continuing operating net profit minus the cash flow from operations for year $t ; T A_{i t-1}$ denotes the assets for year $t-1 ; \Delta S A L E S_{i t}$ is the change in sales for year $t$; $\triangle A R_{i t}$ is the change in account receivables for year $t$; and $P P E_{i t}$ is the gross fixed assets for year t. (Dechow et al., 1995) 


$$
\frac{C A C_{i t}}{T A_{i t-1}}=\beta_{1} \frac{1}{T A_{i t-1}}+\beta_{2} \frac{\Delta R E V_{i t}-\Delta R E C_{i t}}{T A_{i t-1}}+\varepsilon_{i t}
$$

where $C A C_{i t}$ is the change in income before extraordinary items minus operating cash flow minus depreciation and amortization expenses; $T A_{i t-1}$ denotes the assets for year $t-1 ; \Delta R E V_{i t}$ is the change in net revenue for year $t$; and $\triangle R E C_{i t}$ represents the change in account receivables for year $t$. (Louis ,2004)

$$
\frac{W C A_{i t}}{A_{i t-1}}=\beta_{0} \frac{1}{T A_{i t-1 .}}+\beta_{1} \frac{\Delta C R_{i t}}{T A_{i t-1}}+\beta_{2} R O A_{i t-1}+\varepsilon_{i t}
$$

where $W C A_{i t}$ represents the total accruals calculated as the continuing operating net profit minus the cash flow from operations for year $t ; T A_{i t-1}$ represents the assets for year $t-1 ; \Delta C R_{i t}$ is the change in net revenue for year $t$; and $R O A_{i t-1}$ is the return on assets for year $t$. (Matsumoto,2002)

\subsubsection{Real Earnings Management}

Roychowdhury (2006) developed empirical models for estimating the typical levels of real business activities, as reflected in the cash flow from operations, production costs, and discretionary expenditures. We use Models 5-7 to estimate the absolute value of $\varepsilon_{i t}$ to measure the abnormal level (namely, REM)

$$
\begin{aligned}
& \frac{C F O_{i t}}{T A_{i t-1}}=\beta_{0} \frac{1}{T A_{i t-1}}+\beta_{1} \frac{S A L E S_{i t}}{T A_{i t-1}}+\beta_{2} \frac{\Delta S A L E S_{i t}}{T A_{i t-1}}+\varepsilon_{i t} \\
& \frac{P R O D_{i t}}{T A_{i t-1}}=\beta_{0} \frac{1}{T A_{i t-1}}+\beta_{1} \frac{S A L E S_{i t}}{T A_{i t-1}}+\beta_{2} \frac{\Delta S A L E S_{i t}}{T A_{i t-1}}+\beta_{3} \frac{\Delta S A L E S_{i t-1}}{T A_{i t-1}} \varepsilon_{i t} \\
& \frac{D I S E X P_{i t}}{T A_{i t-1}}=\beta_{0} \frac{1}{T A_{i t-1}}+\beta_{2} \frac{S A L E S_{i t-1}}{T A_{i t-1}}+\varepsilon_{i t}
\end{aligned}
$$

where $\mathrm{CFO}_{i t}$ is the cash flow from operations for year $t ; P R O D_{i t}$ is the sum of the cost of goods for sales and the change in inventory for year $t$; DISEXP $P_{i t}$ represents discretionary expenses according to the sum of advertising, R\&D, and sales, as well as general and administrative expenses for year $t ; T A_{i t-1}$ is the assets for year $t-; S A L E S_{i t}$ is the sales for year $t$; $\triangle S A L E S_{i t}$ is the change in sales for year $t ; \triangle S A L E S_{i t-1}$ is the change in sales for year $t-1$; and $S A L E S_{i t-1}$ represents the sales for year $t-1$.

\subsection{Economic Value Added (EVA)}

This research defines the EVA model in three ways (Huang \& Liu, 2010).

\subsubsection{EVA1: (unadjusted EVA) $=$ NOPAT- $\left(\right.$ WACC $\left.^{1} \times I C\right)$}

NOPAT $=$ Pretax operating income (1- cash tax rate)

Invest capital(IC) = asset- non bear debt $^{2}$ - short term securities investment - construction in process

\footnotetext{
${ }^{1}$ Weight average capital cost $($ WACC) $=[($ interest expense/debt $) \times($ debt/capital) $\times(1$-tax rate $)]+$ equity cost $\times$ (equity/capital) ; equity cost is measured by CAPM model (risk free is calculated by fixed deposit interest rate in one year ; market return is calculated by return of market portfolio)

${ }^{2}$ No bear debt $=$ account payable + account notes + accrued expense + pre-earned revenue + other account payable + account tax payable + other current liabilities
} 


\subsubsection{EVA2: adjusted EVA (join adjusted items) = NOPAT- (WACC $\times$ IC)}

NOPAT $=$ pretax operating income $(1$-cash tax rate $)+$ adjustment items ${ }^{3}$

Invest capital(IC) = asset-non bear debt -short term securities investment - construction in process + adjusted items

\subsubsection{EVA3: adjusted EVA (join economic deprecation adjusted items)}

\section{$=$ NOPAT- $($ WACC $\times$ IC $)=$ pretax operating income (1-cash tax rate) + adjustment items \pm economic deprecation adjusted items ${ }^{4}$}

Invest capital= asset- non bear debt - short term securities investment- construction in process + adjusted items

According to the distribution of the Economic value added, we can classify the Economic value added into two groups. The labels " 1 is defined as "economic value added is within or above zero. However, in order to segregate the observations within or above zero, the label " 0 " represents the economic value added is below zero.

\subsection{Model}

The paper adopts logistic regression model, support vector machines (SVM) and rough sets theory (RST) to estimate parameters.

\section{(1) Logistic Regression Model}

$$
\lambda=\ln \frac{\mathrm{p}}{1-\mathrm{p}}=\beta_{0}+\beta_{1} \mathrm{x}_{1}+\cdots \beta_{\mathrm{i}} \mathrm{x}_{\mathrm{i}}
$$

According to the definition of logistic function

$$
\begin{aligned}
& \mathrm{p}=\exp (\alpha+\beta \mathrm{x}) /[1+\exp (\alpha+\beta \mathrm{x})] \\
& 1-\mathrm{P}=1 /[1+\exp (\alpha+\beta \mathrm{x})]
\end{aligned}
$$

$\alpha, \beta_{1} \ldots . . \beta_{\mathrm{m}}$ are return parameters in the model

When the dependent variable is 0,1 variable, the results are in two situations of occurrence (the dependent variable is 1 ) or non-occurrence (the dependent variable is 0 ). The model expressions are as follows:

$$
\begin{aligned}
& P(Y=1)=\frac{\exp (\lambda)}{1+\exp (\lambda)} \\
& P(Y=0)=\frac{\exp (\lambda)}{1+\exp (\lambda)}
\end{aligned}
$$

Equation (11) and (12) show that $P(Y=1)=1-P(Y=0)$

\section{(2) Support Vector Machines (SVM)}

Support vector machines are a set of related supervised learning methods used for classification and regression. Viewing input data as two sets of vectors (two classes classification) in an high dimensional transformed space, an SVM seeks to construct a separating hyper-plane in that space, one which maximizes the margin between the two data sets. To calculate the margin, two parallel hyper-planes are constructed, one on each side of the separating hyper-plane, which are "pushed up against" the two data sets. Intuitively, a good separation is achieved by the hyper plane that has the largest distance to the neighboring data points of both classes, since in general the larger the margin the better the generalization error of the classifier. That is, based on the structured risk minimization principle, SVMs seek to minimize an upper bound of the generalization error instead of the empirical error as in neural networks.

$$
y=\operatorname{sign}\left(w^{\top} \emptyset(X)+b\right), y \in\{-1.1\}
$$

where $y$ is output ( 1 for type $A,-1$ for type $B$ ); $\emptyset(X)$ is a nonlinear mapping form the input space to the high dimensional transformed space. SVMs exploit the idea of mapping input data into a high dimensional reproducing kernel Hilbert space

\footnotetext{
${ }^{3}$ Adjust items $=$ un-amortization research expense( 5 years, Straight-line method $\left.)\right)+$ un-amortization marketing expense(5 years, Straightline method)) + allowance for account receivable + allowance for loss on inventory + allowance for loss on short term investment securities.

${ }^{4}$ Economic deprecation adjusted items is measured by funds method.
} 
(RKHS) where classification could be easily performed. Coefficients $W$ and $b$ are estimated by the following optimization problem

$$
\min _{\mathrm{w}, \mathrm{b}} R\left(\mathrm{w}_{s} \xi\right)=\frac{1}{2}\|\mathrm{w}\|^{2}+\mathrm{C} \sum_{\mathrm{i}=1}^{\mathrm{m}} \quad \xi_{\mathrm{i}}
$$

with $y_{i}\left(w^{1} \Phi(X)+b\right) \geq 1+\xi_{i}, i=1 \ldots \ldots \ldots \ldots . . m \quad \xi_{i} \geq 0$

$\mathrm{C}$ is a prescribed parameter to evaluates the trade-off between the empirical risk and the smoothness of the model.

\section{(3) Rough Set}

Rough sets theory (RST) is a machine-learning method has proved to be a powerful tool for uncertainty and has been applied to data reduction, rule extraction, data mining and granularity computation. Here, we illustrate only the relevant basic ideas of RST that are relevant to the present work.

By an information system we understand the 4-tuple $S=(U, A, V, f)$, where $U$ is a finite set of objects, called the universe, $A$ is a finite set of attributes, $V=U_{\mathrm{a} \in A} V_{\mathrm{a}}$ is a domain of attribute $a$, and $f: U \times A \rightarrow V$ is called an information function such that $f(\mathrm{x}, \mathrm{a}) \in \mathrm{v}_{\mathrm{a}}$, for $\forall a \in A, \forall \mathrm{x} \in \mathbb{U}$. In the classification problems, an information system is also seen as a decision table assuming that $A=C \cup D$ and $C \cap D=\emptyset$, where $C$ a set of condition attributes and $D$ is a set of decision attributes

Let $S=(U, A, V, f)$ be an information system, every $P \subseteq A$ generates an in-discernibility relation IND $(P)$ on $U$, which is defined as follows:

$$
\operatorname{IND}(\mathrm{P})=\{(\mathrm{x}, \mathrm{y}) \in \mathbb{U} \times \mathbb{U}: f(y, a), \forall a \in P\}
$$

$\mathrm{U} / \mathrm{IND}(\mathrm{P})=\left\{\mathrm{C}_{1}, \mathrm{C}_{2} \ldots \ldots \ldots \mathrm{C}_{\mathrm{K}}\right\}$ is a partition of $\mathrm{U}$ by $\mathrm{P}$, every $\mathrm{C}_{\mathrm{I}}$ is an equivalence class. For $\forall \mathrm{X} \in \mathbb{U}$ the equivalence class of $x$ in relation to $U / I N D(P)$ is defined as follows:

$$
[\mathrm{X}]_{\mathrm{U} / \mathrm{IND}(\mathrm{P}]}=\{\mathrm{y} \in \mathrm{U}: f(y, a)=f(x, a), \forall a \in \mathrm{P}\}
$$

Let $\mathrm{P} \subseteq \mathrm{A}$ and $\mathrm{X} \subseteq \mathrm{U}$. The $\mathrm{P}$-lower approximation of $\mathrm{x}$ (denoted by $\mathrm{P}_{*}(\mathrm{x})$ ) and the $\mathrm{P}$-upper approximation of $\mathrm{x}$ (denoted by $\left.\mathbf{P}^{*}(\mathrm{x})\right)$ are defined as follows:

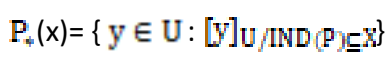

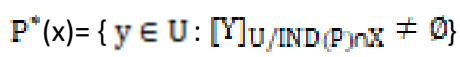

where $P^{*}(x)$ is the set of all objects form $U$ which can certainly be classified as elements of $x$ employing the set of attributes $P . P^{*}(x)$ is the set of objects of $U$ which can be classified as elements of $x$ using the set of attributes $P$. Let $P, Q \subseteq A$, the positive region of classification $U / I N D(Q)$ with respect to the set of attributes $P$, or in

Short, $\mathrm{P}$-positive region of $\mathrm{Q}$ is defined as $\mathrm{POS}(\mathrm{Q})=\mathrm{U}_{\mathrm{X} \in \mathrm{U} / \mathrm{IND}} \mathrm{Q}, \mathrm{P}(\mathrm{X})$.

POS $_{p}(Q)$ contains objects in $U$ that can be classified to one class of the classificationU/IND(Q) by attributes $P$. The dependency of $Q$ on $P$ is defined as

$$
\mathrm{Y}_{\mathrm{p}}(\mathrm{Q})=\operatorname{card}\left(\mathrm{POS}_{\mathrm{p}}(\mathrm{Q})\right) / \operatorname{card}(\mathrm{U})
$$

An attribute $\mathrm{a}$ is said to be dispensable in $\mathrm{P}$ with respect to

$Q$, if $Y_{p}(Q)=\lambda_{p}-\{a\}(Q) ;$ otherwise $a$ is an indispensable

attribute in $\mathrm{P}$ with respect to $\mathrm{Q}$. $\subset$

Let $S=(U, A, V, f)$ be a decision table, the set of attributes

$P(P \subseteq C)$ is a reduce of attributes $C$, which satisfies the following

Conditions:

$Y_{p}(D)=Y_{c}(D), Y_{p}(D) \neq Y_{p}(D) \forall P^{p} \subset P$.

A reduce of condition attributes $C$ is a subset that can discern decision classes with the same Accuracy as $C$, and none of the attributes in the reduced can be eliminated without decreasing its distrainable capability 


\subsection{Variables Selection}

To pick out the factors that are informative and closely related to the economic value added, we employ feature selection. In fact, the feature selection is a part of the complex and comprehensive of data mining. We employ paired t-test to evaluate significance of difference of each factor between economic value added above and below zero. Thus, we use the following variables (Vijaykumar,2010; Chen and Qiao, 2008): market value added is used to the market value of the firm's equity minus the book value of the firm's equity; earnings per share is used to net income/outstanding shares; account receivable turnover is used to net credit sales/ average account receivables; asset turnover is used to sales or revenues/total assets

\subsection{Robustness Test}

In order to avoid possible bias from extreme values, the study also adopt those samples only include the sample data of from the 5th percentile to the 95th percentile as measures for the robustness test (Huang \& Liu, 2011)

\section{EMPIRICAL RESULTS}

\subsection{Descriptive Statistics}

According to the descriptive statistics shown in Table 1, the mean EVA1 (unadjusted items), EVA2 (adjusted items) and EVA3 (join adjusted items and economic deprecation adjusted items) is lower in China. According to performance index (US\$ billions), EVA1 (unadjusted items) or EVA2 (adjusted items) are in Latin-America nations and EVA3 (join adjusted items and economic deprecation adjusted items) is higher in Africa nations. In addition, the earnings per share above zero and the positive market value added show that financial conditions have been conservative in these nations.

Tables 2-8 show the descriptive statistics obtained through the earnings management model. Abnormal cash flow from operations had stronger explanatory power $\left(R^{2}=0.494\right)$ in China. Abnormal discretionary expenses had stronger explanatory power for earnings management ( $\left.R^{2}=0.512\right)$ in African nations. Discretionary working capital accruals had stronger explanatory power for earnings management ( $\left.R^{2}=0.519\right)$ in Latin-America nations. Overall, these empirical results show that real business activities (e.g., abnormal cash flow from operations or abnormal discretionary expenses) are more effective for explain earnings management in these nations.

Table 1: Descriptive Statistics - All Samples (US\$ billions, per value or \%)

\begin{tabular}{lccc|}
\hline & China & Africa & Latin America \\
\hline$E V A_{i t .1}$ & 89.442 & 155.242 & 195.462 \\
$E V A_{i t .2}$ & 79.518 & 136.421 & 173.367 \\
$E V A_{i t, 3}$ & 77.463 & 105.247 & 99.127 \\
$M V A_{i t}$ & 128.362 & 112.079 & 117.352 \\
$E P S_{i t}$ & 1.25 & 1.49 & 1.38 \\
$A R T_{i t}$ & 0.341 & 0.446 & 0.524 \\
$A T_{i t}$ & 0.221 & 0.247 & 0.386 \\
\hline Sample & 12392 & 2416 & 5616 \\
\hline
\end{tabular}

where $E V A_{i t, n}$ is the economic value added ( $n=1$ for unadjusted EVA; $n=2$ for adjusted EVA, join adjusted items; $n=3$ for adjusted EVA, join adjusted items and economic deprecation adjusted items); $M V A_{i t}$ represents a firm's market value added for year $t ; E P S_{i t}$ is the earnings per share for year $t$; and $A R T_{i t}$ denotes the account receivable turnover for year t; $A T_{i t}$ denotes the asset turnover for year $t .^{* * *}$ indicates statistic significant at $1 \%$ level; $* *$ at $5 \%$ level; and $*$ at $10 \%$ level. 
Table 2: Descriptive Statistics of the Estimated Cross-Section of the Jones Model

\begin{tabular}{cccc|}
\hline & & \multicolumn{2}{c|}{ Dependent Variable: $M A C C_{i t} / T A_{i t-1}$} \\
\hline & China & Africa & Latin America \\
\hline $1 / T A_{i t-1}$ & 0.055 & 0.072 & 0.084 \\
$\frac{\Delta N E T R E V_{i t}}{T A_{i t-1}}$ & $0.062^{* * *}$ & -0.091 & $0.377^{* * *}$ \\
$P P E_{i t}$ & & & 0.084 \\
\hline$T A_{i t-1}$ & $0.062^{* * *}$ & $-0.159^{* *}$ & $11.721^{* * *}$ \\
F-value & $12.389^{* * *}$ & $10.679^{* * *}$ & 0.183 \\
\hline$R^{2}$ & 0.255 & 0.156 & 5616 \\
\hline Sample & 12392 & 2416 &
\end{tabular}

where $M A C C_{i t}$ is the total accruals calculated as the change in non-cash current assets minus the change in current liabilities minus the depreciation expense for year $\mathrm{t} ; \quad T A_{i t-1}$ is the assets for year $t-1 ; \triangle N E T R E V_{i t}$ is the change in net revenue for year $\mathrm{t} ;{ }^{P P E_{i t}}$ is the gross fixed assets for year t. ${ }^{* * *}$ indicates statistic significant at $1 \%$ level; ${ }^{* *}$ at $5 \%$ level; and $*$ at $10 \%$ level.

Table 3: Descriptive Statistics for the Estimated Cross Section of the Modified Jones Model

\begin{tabular}{c|ccc}
\hline & & \multicolumn{3}{c}{ Dependent Variable: $A C C_{i t} / T A_{i t-1}$} \\
\hline & China & Africa & Latin America \\
\hline $1 / T A_{i t-1}$ & $-0.178^{* *}$ & 0.221 & $-0.187^{* * *}$ \\
$\frac{\Delta S A L E S_{i t}-\Delta A R_{i t}}{T A_{i t-1}}$ & $0.445^{* * *}$ & $0.276^{* * *}$ & $0.319^{* * *}$ \\
$\frac{P P E_{i t}}{T A_{i t-1}}$ & & & $-0.282^{* *}$ \\
F-value & 0.192 & $-0.256^{* *}$ & $15.467^{* * *}$ \\
$R^{2}$ & $11.458^{* * *}$ & $11.847^{* * *}$ & 0.342 \\
\hline Sample & 0.224 & 0.238 & 5616 \\
\hline
\end{tabular}

where $A C C_{i t}$ represents the total accruals calculated as the continuing operating net profit minus the cash flow from operations for year $t ; T A_{i t-1}$ denotes the assets for year $t-1 ; \triangle S A L E S_{i t}$ is the change in sales for year $t$; $\triangle A R_{i t}$ is the change in account receivables for year $t$; and $P P E_{i t}$ is the gross fixed assets for year $\mathrm{t} . * * *$ indicates statistic significant at $1 \%$ level; ** at $5 \%$ level; and * at $10 \%$ level.

Table 4: Descriptive Statistics for the Estimated Cross-Section of Current Discretionary Accruals

\begin{tabular}{cccc|}
\hline & & \multicolumn{2}{c|}{ Dependent Variable: $C A C_{i t} /{ }^{T A_{i t-1}}$} \\
\hline & China & Africa & Latin America \\
\hline $1 / T A_{i t-1}$ & $0.092^{* *}$ & 0.055 & 0.072 \\
$\Delta R E V_{i t}-\Delta R E C_{i t}$ & -0.041 & $-0.072^{* *}$ & $0.128^{* * *}$ \\
\hline$T A_{i t-1}$ & & & \\
F-value & $12.006^{* * *}$ & $11.446^{* * *}$ & $14.115^{* * *}$ \\
$R^{2}$ & 0.317 & 0.308 & 0.352 \\
\hline Sample & 12392 & 2416 & 5616 \\
\hline
\end{tabular}


where $C A C_{i t}$ is the change in income before extraordinary items minus operating cash flow minus depreciation and amortization expenses; $T A_{i t-1}$ denotes the assets for year $t-1 ; \Delta R E V_{i t}$ is the change in net revenue for year $t$; and $\triangle R E C_{i t}$ represents the change in account receivables for year $t .{ }^{* *}$ indicates statistic significant at $1 \%$ level; ${ }^{* *}$ at $5 \%$ level; and * at $10 \%$ level.

Table 5: Descriptive Statistics for the Estimated Cross-Section of Working Capital Accruals

\begin{tabular}{|c|c|c|c|}
\hline & \multicolumn{3}{|c|}{ Dependent Variable: $W C A_{i t} / T A_{i t-1}$} \\
\hline & China & Africa & Latin America \\
\hline $1 / T A_{i t-1}$ & -0.118 & $0.367 * *$ & $-0.528 * * *$ \\
\hline$\frac{\Delta C R_{i t}}{T A_{i t-1}}$ & 0.272 & $0.202 *$ & $-.0 .419 * * *$ \\
\hline$R O A_{i t-1}$ & $0.617^{*}$ & $0.862 * * *$ & $-0.868 * *$ \\
\hline F-value & $11.005^{* * *}$ & $12.319 * * *$ & $16.441^{* * *}$ \\
\hline$R^{2}$ & 0.348 & 0.418 & 0.519 \\
\hline Sample & 12392 & 2416 & 5616 \\
\hline
\end{tabular}

where $W C A_{i t}$ represents the total accruals calculated as the continuing operating net profit minus the cash flow from operations for year $t ; T A_{i t-1}$ represents the assets for year $t-1 ; \Delta C R_{i t}$ is the change in net revenue for year $t$; and $R O A_{i t-1}$ is the return on assets for year $t .{ }^{* *}$ indicates statistic significant at $1 \%$ level; ${ }^{* *}$ at $5 \%$ level; and $*$ at $10 \%$ level.

Table 6: Descriptive Statistics for the Estimated Cross-Section of Abnormal Cash Flow from Operations

\begin{tabular}{cccc|}
\hline & & \multicolumn{2}{c|}{ Dependent Variable: $C F O_{i t} / T A_{i t-1}$} \\
\hline & China & Africa & Latin America \\
\hline $1 / T A_{i t-1}$ & $0.641^{*}$ & $-1.124^{* * *}$ & $-0.781^{* *}$ \\
$\frac{}{S A L E S_{i t}}$ & $0.546^{* *}$ & $-0.918^{* * *}$ & -0.763 \\
$T A_{i t-1}$ & & & \\
$\frac{\Delta S A L E S_{i t}}{T A_{i t-1}}$ & $0.716^{* *}$ & $-0.772^{* *}$ & 0.214 \\
F-value & $11.056^{* * *}$ & $10.092^{* * *}$ & $9.265^{* *}$ \\
$R^{2}$ & 0.494 & 0.387 & 0.325 \\
\hline Sample & 12392 & 2416 & 5616 \\
\hline
\end{tabular}

where $C F O_{i t}$ is the cash flow from operations for year $t ; T A_{i t-1}$ is the assets for year $t-1 ; S A L E S_{i t}$ is the sales for year $t ; \triangle S A L E S_{i t}$ is the change in sales for year $t ; * * *$ indicates statistic significant at $1 \%$ level; ** at $5 \%$ level; and * at $10 \%$ level. 
Table 7: Descriptive Statistics for the Estimated Cross-Section of Abnormal Production Costs

\begin{tabular}{c|ccc}
\hline & \multicolumn{3}{|c}{ Dependent Variable: $P R O D_{i t} / T A_{i t-1}$} \\
\hline & China & Africa & Latin America \\
\hline $1 / T A_{i t-1}$ & $0.176^{*}$ & $0.164^{* * *}$ & $0.419^{* * *}$ \\
$\frac{S A L E S_{i t}}{T A_{i t-1}}$ & $0.216^{* * *}$ & $0.325^{* * *}$ & -0.116 \\
$\frac{\Delta S A L E S_{i t}}{T A_{i t-1}}$ & 0.128 & -0.194 & $0.195^{* *}$ \\
$\frac{\Delta S A E S_{i t-1}}{T A_{i t-1}}$ & $-0.204^{* *}$ & $-0.216^{* *}$ & $-0.292^{*}$ \\
F-value & 12.446 & 16.184 & 12.105 \\
$R^{2}$ & 0.264 & 0.502 & 0.246 \\
\hline Sample & 12392 & 2416 & 5616 \\
\hline
\end{tabular}

where $P R O D_{i t}$ is the sum of the cost of goods for sales and the change in inventory for year $t ; T A_{i t-1}$ is the assets for year $t-1 ; S A L E S_{i t}$ is the sales for year $t ; \triangle S A L E S_{i t}$ is the change in sales for year $t ; \triangle S A L E S_{i t-1}$ is the change in sales for year $t-1{ }^{* * *}$ indicates statistic significant at $1 \%$ level; ** at $5 \%$ level; and $*$ at $10 \%$ level.

Table 8: Descriptive Statistics for the Estimated Cross Section of Abnormal Discretionary Expenses

\begin{tabular}{cccc|}
\hline & & \multicolumn{2}{c|}{ Dependent Variable: $D I S E X P_{i t} / T A_{i t-1}$} \\
\hline & China & Africa & Latin America \\
\hline $1 / T A_{i t-1}$ & $0.652^{* * *}$ & $0.164^{* *}$ & $0.121^{*}$ \\
$S A L E S_{i t-1}$ & $0.486^{* * *}$ & $0.208^{* * *}$ & $0.194^{* *}$ \\
$T A_{i t-1}$ & $10.442^{* * *}$ & $12.187^{* * *}$ & $12.056^{* * *}$ \\
F-value & 0.304 & 0.512 & 0.486 \\
$R^{2}$ & 12392 & 2416 & 5616 \\
\hline Sample & & & \\
\hline
\end{tabular}

where DISEXP ${ }_{i t}$ represents discretionary expenses according to the sum of advertising, R\&D, and sales, as well as general and administrative expenses for year $t ; A_{i t-1}$ is the assets for year $t-1 ; S A L E S_{i t-1}$ represents the sales for year $t-1 .{ }^{* * *}$ indicates statistic significant at $1 \%$ level; ${ }^{* *}$ at $5 \%$ level; and ${ }^{*}$ at $10 \%$ level.

\subsection{Empirical Test}

The comparisons of predicted and actual classifications are shown in Tables 9-11. Because the financial crisis of 2008 might have restructured the global financial market, we separated data after 2008 to obtain the accuracy of model.

As indicated in Table 9 (China), RST model had the highest accuracy (the accuracy was 57.53\%) when the earnings management was DAs of the modified Jones model employed to predict adjusted economic value added (join adjusted items and economic deprecation adjusted items), and logit model possessed the lowest accuracy (the accuracy was 38.07\%) when the earnings management was the abnormal level of production costs employed to predict un-adjusted economic value added. In addition, the results show that the RST model has stronger explanatory power (the accuracy was $57.04 \%$ ) for predicting adjusted economic value added (join adjusted items and economic deprecation adjusted items) when Jones model was employed to predict economic value added; RST model has stronger explanatory power (the accuracy was $57.53 \%$ ) for predicting adjusted economic value added (join adjusted items and economic deprecation adjusted items) when Modified Jones model was employed to predict economic value added; SVM model has stronger explanatory power (the accuracy was 52.34\%) for predicting adjusted economic value added (join adjusted items and economic deprecation adjusted items) when current discretionary accruals was employed to predict economic value added ; RST model has 
stronger explanatory power (the accuracy was 53.46\%) for predicting adjusted economic value added (join adjusted items and economic deprecation adjusted items) when working capital accruals model was employed to predict economic value added; RST model has stronger explanatory power (the accuracy was 53.88\%) for predicting adjusted economic value added (join adjusted items and economic deprecation adjusted items) when abnormal cash flow from operations model was employed to predict economic value added ; RST model has stronger explanatory power (the accuracy was 52.94\%) for predicting adjusted economic value added (join adjusted items and economic deprecation adjusted items) when abnormal production costs model was employed to predict economic value added ; logit model has stronger explanatory power (the accuracy was $53.10 \%$ ) for predicting adjusted economic value added (join adjusted items and economic deprecation adjusted items) when abnormal discretionary expenses was employed to predict economic value added.

As indicated in Table 10 (Africa nations), RST model had the highest accuracy (the accuracy was 57.59\%) when the earnings management was the current DAs employed to predict adjusted economic value added (join adjusted items and economic deprecation adjusted items), and logit model possessed the lowest accuracy (the accuracy was $34.41 \%$ ) when the earnings management was the abnormal level of cash flow from operations employed to predict adjusted economic value added. (join adjusted items). In addition, the results show that the RST model has stronger explanatory power (the accuracy was $54.20 \%$ ) for predicting adjusted economic value added (join adjusted items and economic deprecation adjusted items) when Jones model was employed to predict economic value added; RST model has stronger explanatory power (the accuracy was $56.47 \%$ ) for predicting adjusted economic value added (join adjusted items and economic deprecation adjusted items) when Modified Jones model was employed to predict economic value added; RST model has stronger explanatory power (the accuracy was $57.59 \%$ ) for predicting adjusted economic value added (join adjusted items and economic deprecation adjusted items) when current discretionary accruals was employed to predict economic value added; RST model has stronger explanatory power (the accuracy was $54.06 \%$ ) for predicting adjusted economic value added (join adjusted items and economic deprecation adjusted items) when working capital accruals model was employed to predict economic value added; RST model has stronger explanatory power (the accuracy was $54.56 \%$ ) for predicting adjusted economic value added (join adjusted items and economic deprecation adjusted items) when abnormal cash flow from operations model was employed to predict economic value added; SVM model has stronger explanatory power (the accuracy was 56.15\%) for predicting adjusted economic value added (join adjusted items and economic deprecation adjusted items) when abnormal production costs model was employed to predict economic value added; SVM model has stronger explanatory power (the accuracy was 56.46\%) for predicting adjusted economic value added (join adjusted items and economic deprecation adjusted items) when abnormal discretionary expenses was employed to predict economic value added.

As indicated in Table 11 (Latin-America nations), SVM model had the highest accuracy (the accuracy was 64.38\%) when the earnings management was DAs of the modified Jones model employed to predict adjusted economic value added (join adjusted items and economic deprecation adjusted items), however SVM model possessed the lowest accuracy (the accuracy was $33.61 \%$ ) when the earnings management was the abnormal level of cash flow from operations employed to predict un-adjusted economic value added. In addition, the results show that the SVM model has stronger explanatory power (the accuracy was 57.75\%) for predicting adjusted economic value added (join adjusted items and economic deprecation adjusted items) when Jones model was employed to predict economic value added ; SVM model has stronger explanatory power (the accuracy was 64.38\%) for predicting adjusted economic value added (join adjusted items and economic deprecation adjusted items) when Modified Jones model was employed to predict economic value added ; SVM model has stronger explanatory power (the accuracy was 59.29\%) for predicting adjusted economic value added (join adjusted items and economic deprecation adjusted items) when current discretionary accruals was employed to predict economic value added ; Logit model has stronger explanatory power (the accuracy was 53.67\%) for predicting unadjusted economic value added when working capital accruals model was employed to predict economic value added ; Logit model has stronger explanatory power (the accuracy was $42.37 \%$ ) for predicting un adjusted economic value added when abnormal cash flow from operations model was employed to predict economic value added ; Logit model has stronger explanatory power (the accuracy was $48.43 \%$ ) for predicting adjusted economic value added (join adjusted items and economic deprecation adjusted items) when abnormal production costs model was employed to predict economic value added; SVM model has stronger explanatory power (the accuracy was 57.14\%) for predicting adjusted economic value added (join adjusted items and economic deprecation adjusted items) when abnormal discretionary expenses was employed to predict economic value added.

The significance in difference provides strong evidences in the prediction trends regarding effect of earnings management on economic value added. On the other hands, in order to avoid possible bias from extreme values, the study also adopt those samples only include the sample data of from the 5th percentile to the 95th percentile as measures for the robustness test, the results show that most of them are consistent. 
Table 9: The Accuracy of Every Prediction Model: China

\begin{tabular}{|c|c|c|c|c|c|c|c|c|c|}
\hline & \multicolumn{9}{|c|}{ Economic Value Added } \\
\hline & \multicolumn{3}{|c|}{$E V A_{i t, n=1}$} & \multicolumn{3}{|c|}{$E V A_{i t, n=2}$} & \multicolumn{3}{|c|}{$E V A_{i t, n=3}$} \\
\hline & Logit & SVM & RST & Logit & SVM & RST & Logit & SVM & RST \\
\hline$D A J_{i t}$ & 46.09 & 48.32 & 51.05 & 52.60 & 53.48 & 54.89 & 53.91 & 55.38 & 57.04 \\
\hline$D A M J_{i t}$ & 47.92 & 49.94 & 51.28 & 53.22 & 52.72 & 53.42 & 55.01 & 56.16 & 57.53 \\
\hline$D A C A_{i t}$ & 42.42 & 48.28 & 49.07 & 50.07 & 50.07 & 51.46 & 51.30 & 52.34 & 52.32 \\
\hline$D A W C_{i t}$ & 41.24 & 45.30 & 47.05 & 48.34 & 50.41 & 50.43 & 51.03 & 53.42 & 53.46 \\
\hline$A B C F O_{i t}$ & 38.76 & 42.92 & 45.21 & 46.44 & 49.20 & 48.41 & 51.20 & 50.98 & 53.88 \\
\hline$A B P C_{i t}$ & 38.07 & 42.24 & 46.23 & 46.85 & 46.95 & 49.51 & 52.75 & 51.29 & 52.94 \\
\hline$A B D E_{i t}$ & 39.11 & 42.72 & 49.07 & 47.81 & 46.15 & 51.08 & 53.10 & 53.01 & 51.16 \\
\hline Sample & & & & & 12392 & & & & \\
\hline
\end{tabular}

where $D A J_{i t}$ denotes the DAs of the Jones model for year $t ; D A M J_{i t}$ represents the DAs of the modified Jones model for year $t ; D A C A_{i t}$ represents the current DAs for year $t ; D A W C_{i t}$ represents the discretionary working capital accruals for year $t ; A B C F O_{i t}$ represents the abnormal level of cash flow from operations for year $t ; A B P C_{i t}$ denotes the abnormal level of production costs for year $t ; A B D E_{i t}$ is the abnormal level of discretionary expenditures for year $t ; E V A_{i t, n}$ is the economic value added ( $n=1$ for unadjusted EVA; $n=2$ for adjusted EVA, join adjusted items; $n=3$ for adjusted EVA, join adjusted items and economic deprecation adjusted items)

Table 10: The Accuracy of Every Prediction Model: African Nations

\begin{tabular}{|c|c|c|c|c|c|c|c|c|c|}
\hline & \multicolumn{9}{|c|}{ Economic Value Added } \\
\hline & \multicolumn{3}{|c|}{$E V A_{i t, n=1}$} & \multicolumn{3}{|c|}{$E V A_{i t, n=2}$} & \multicolumn{3}{|c|}{$E V A_{i t, n=3}$} \\
\hline & Logit & SVM & RST & Logit & SVM & RST & Logit & SVM & RST \\
\hline$D A J_{i t}$ & 38.93 & 45.18 & 39.66 & 48.48 & 51.89 & 51.47 & 53.29 & 49.38 & 54.20 \\
\hline$D A M J_{i t}$ & 38.34 & 47.83 & 50.28 & 45.33 & 49.26 & 43.81 & 54.06 & 55.25 & 56.47 \\
\hline$D A C A_{i t}$ & 40.34 & 38.03 & 51.12 & 51.16 & 51.16 & 47.23 & 47.33 & 54.23 & 57.59 \\
\hline$D A W C_{i t}$ & 44.40 & 41.20 & 46.97 & 49.20 & 44.75 & 50.51 & 50.23 & 47.88 & 54.06 \\
\hline$A B C F O_{i t}$ & 34.41 & 44.35 & 49.29 & 47.26 & 45.18 & 52.33 & 51.44 & 54.30 & 54.56 \\
\hline$A B P C_{i t}$ & 45.22 & 36.26 & 44.35 & 49.28 & 49.42 & 46.20 & 48.24 & 56.15 & 54.25 \\
\hline$A B D E_{i t}$ & 37.85 & 48.28 & 51.02 & 51.43 & 48.96 & 51.61 & 47.25 & 56.46 & 47.88 \\
\hline Sample & & & & & 2416 & & & & \\
\hline
\end{tabular}

where $D A J_{i t}$ denotes the DAs of the Jones model for year $t ; D A M J_{i t}$ represents the DAs of the modified Jones model for year $t$; $D A C A_{i t}$ represents the current DAs for year $t$; $D A W C_{i t}$ represents the discretionary working capital accruals for year $t ;{ }^{A B C F O_{i t}}$ represents the abnormal level of cash flow from operations for year $t ; A B P C_{i t}$ denotes the abnormal level of production costs for year $t ; A B D E_{i t}$ is the abnormal level of discretionary expenditures for year $t ; E V A_{i t, n}$ is the economic value added ( $n=1$ for unadjusted EVA; $n=2$ for adjusted EVA, join adjusted items; $n=3$ for adjusted EVA, join adjusted items and economic deprecation adjusted items) 
Table 11: The Accuracy of Every Prediction Model (\%): Latin-American Nations

\begin{tabular}{|c|c|c|c|c|c|c|c|c|c|}
\hline & \multicolumn{9}{|c|}{ Economic Value Added } \\
\hline & \multicolumn{3}{|c|}{$E V A_{i t, n=1}$} & \multicolumn{3}{|c|}{$E V A_{i t, n=2}$} & \multicolumn{3}{|c|}{$E V A_{i t, n=3}$} \\
\hline & Logit & SVM & RST & Logit & SVM & RST & Logit & SVM & RST \\
\hline$D A J_{i t}$ & 42.72 & 53.48 & 48.66 & 41.41 & 53.79 & 46.64 & 37.95 & 57.75 & 51.60 \\
\hline$D A M J_{i t}$ & 54.01 & 60.07 & 58.95 & 51.93 & 60.38 & 56.45 & 47.22 & 64.38 & 62.08 \\
\hline$D A C A_{i t}$ & 48.39 & 55.50 & 52.58 & 46.52 & 55.82 & 50.58 & 42.45 & 59.29 & 55.35 \\
\hline$D A W C_{i t}$ & 53.67 & 40.23 & 48.81 & 51.62 & 40.75 & 46.72 & 47.47 & 42.97 & 51.28 \\
\hline$A B C F O_{i t}$ & 42.73 & 33.88 & 39.22 & 41.53 & 33.61 & 36.91 & 38.02 & 35.99 & 40.41 \\
\hline$A B P C_{i t}$ & 48.43 & 38.22 & 44.81 & 46.89 & 38.37 & 42.97 & 42.43 & 40.82 & 47.13 \\
\hline$A B D E_{i t}$ & 43.07 & 53.48 & 49.25 & 41.41 & 53.79 & 46.64 & 37.95 & 57.14 & 51.21 \\
\hline Sample & & & & & 5616 & & & & \\
\hline
\end{tabular}

where $D A J_{i t}$ denotes the DAs of the Jones model for year $t ; D A M J_{i t}$ represents the DAs of the modified Jones model for year $t$; $D A C A_{i t}$ represents the current DAs for year $t ; D A W C_{i t}$ represents the discretionary working capital accruals for year $t ; A B C F O_{i t}$ represents the abnormal level of cash flow from operations for year $t ; A B P C_{i t}$ denotes the abnormal level of production costs for year $t ; A B D E_{i t}$ is the abnormal level of discretionary expenditures for year $t ; E V A_{i t, n}$ is the economic value added ( $n=1$ for unadjusted EVA; $n=2$ for adjusted EVA, join adjusted items; $n=3$ for adjusted EVA, join adjusted items and economic deprecation adjusted items)

\section{CONCLUSION}

Several nations have suffered severe losses since the 2008 financial tsunami; consequently, acquiring external funds has become more costly and difficult. Economic value added (EVA), is used to evaluate economic value, assess funds, and efficiently allocate resources, and it involves using adjustment items to reflect the true economic value of a firm. However, EVA is also based on financial statements for measuring opponents, it is highly probable that EVA motivates managers to engage in earnings management behavior. Overall, EVA may not reflect true performance. Thus, managers attempting to adopt earnings management for generating a more favorable image of businesses and for acquiring external funds more cheaply or easily may have affected business capital costs and economic value added (Wang et al., 2015).

We adopted a logit, SVM, RST model to analyze data from 2009 to 2016 from the COMPUSTAT database (including China, Africa nations, Latin America nations). We also adopted REM activities and DA items to measure earnings management, unadjusted EVA, adjusted EVA (join adjusted items, join adjusted items and economic deprecation adjusted items) for determining EVA.

The results indicate that RST model had the highest accuracy when the earnings management was DAs of the modified Jones model employed to predict adjusted economic value added (join adjusted items and economic deprecation adjusted items) in China; RST model had the highest accuracy when the earnings management was the current DAs employed to predict adjusted economic value added (join adjusted items and economic deprecation adjusted items) in Africa nations; SVM model had the highest accuracy when the earnings management was DAs of the modified Jones model employed to predict adjusted economic value added (join adjusted items and economic deprecation adjusted items) in Latin-America nations.

Our results provide critical implications for managers, researchers, investors, and regulators. Managers should analyze whether EVA motivates managers to engage in earnings management behavior. For researchers, we adopted logit, SVM and RST model to predict effect of earnings management on economic value added; however, these models are subjective, and optimal model should be analyzed in the future. Numerous factors affect EVA, such as differences among cultures, national and international laws and regulations, and economic development. Therefore, future studies should examine all relevant factors or devise new theories that predict economic value added. For investors, they can analyze the true value of enterprises, regardless of whether enterprises have adopted earnings management. Regulators (e.g., governments) should establish stricter security measures and laws or rules for listed firms to prevent earnings management following a financial tsunami and to encourage them to report their "real" true value. 
Future studies should consider refining the measurement of the earnings management model because not all of them are equal, and it is unlikely that the consequences of engaging in earnings management are equal in all capital markets. In addition, researchers may also consider focusing on identifying intermediary variables affecting these relationships or establishing an optimal theory for explaining the relationship between earnings management and EVA

\section{REFERENCES}

Abraham, R., Harris, J., Auerbach, J. (2017). Earnings yield as a predictor of return on assets, return on equity, economic value added and the equity multiplier. Modern Economy, 8,10-24.

Ali, A., Zhang, W. (2015). CEO tenure and earnings management. Journal of Accounting and Economics, 59,60-79.

Ali, S. M., Salleh, N. M., Hassan, M. S. (2008). Ownership structure and earnings management in Malaysian listed companies: the size effect. Asian Journal of Business and Accounting, 1(2),89-116.

Alves, S. (2012). Ownership structure and earnings management: evidence from Portugal. Australasian Accounting, Business and Finance Journal, 6(1),57-74.

Badertscher, B. A. (2011). Overvaluation and the choice of alternative earnings management mechanisms. The Accounting Review, 86(5), 1491-1518.

Badolato, P. G., Donelson, D. C., Ege, M. (2014). Audit committee financial expertise and earnings management: the role of status. Journal of Accounting and Economics,58,208-230.

Banderlipe, M. R. (2009). The impact of selected corporate governance variables in mitigating earnings management in the Philippines. DLSU Business \& Economics Review, 19(1),17-27.

Bhasin, M. (2012). Economic value added and corporate performance measurement: the portrait of a developing country. International journal of Contemporary Business Studies, 3(8),19-37.

Bhojraj, S., Hribar P., Picconi M., Mclnnis. J. (2009). Making sense of cents: an examination of firms that marginally miss or beat analyst forecasts. Journal of Finance ,64(5), 2361-2388.

Campa, D., Camacho-Miñano, M. M. (2015). The impact of SME's pre-bankruptcy financial distress on earnings management tools. International Review of Financial Analysis, 42,222-234.

Chen, L., Wang, S. Y., Qiao Z. (2014). Dupont model and product profitability analysis based on activity-based costing and economic value added. European Journal of Business and Management, 6(30),25-35.

Chen, L., Qiao, Z. (2008). What influence the company's economic value added? empirical evidence from china's securities market. Management Science and Engineering, 2(1),66-76.

Chen, C. L., Huang, S. H., Fan, H. S. (2012). Complementary association between real activities and accruals-based manipulation in earnings reporting. Journal of Economic Policy Reform, 15(2),93-108.

Chen, F., Chi, D., Wang, Y. (2015). Detecting biotechnology industry's earnings management using Bayesian network, principal component analysis, back propagation neural network, and decision tree. Economic Modelling, vol.23, pp.461-510.

Chen, T. Y., Gu, Z. Y., Kubota, K., Takehara, H. (2015). Accrual-based and real activities based earnings management behavior of family firms in Japan. The Japanese Accounting Review,5,21-47.

Chih, H. L., Shen, C.H., Kang, F. C. (2008). Corporate social responsibility, investor protection, and earnings management: some international evidence. Journal of Business Ethics, 79,179-198.

Cohen, D. A., Dey, A., Lys, T. (2008). Real and accrual-based earnings management in the pre- and post-sarbanes-oxley periods. The Accounting Review, 83(3),757-787.

Collins, D. W., Pungaliya, R. S., Vijh A. M. (2017). The effects of firm growth and model specification choices on tests of earnings management in quarterly settings. The Accounting Review, 92(2), 69-100.

Cornett, M., Marcus, A., Tehranian, H. (2008). Corporate governance and pay-for-performance: the impact of earnings management. Journal of Financial Economics, 87, 357-373.

Datta, S., Iskandar-Datta, M., Singh, V. (2013). Product market power, industry structure, and corporate earnings management. Journal of Banking and Finance, 37(8),3273-3285.

Davidson, W., Xie, B., Xu, W., Ning, Y. (2007). The influence of executive age, career horizon and incentives on pre-turnover earnings management. Journal of Management \& Governance, 11,45-60.

Dechow, P., Sloan, R., Sweeny, A. (1995). Detecting earnings management. The Accounting Review,70,193-225. 
Dechow, P. M., Hutton, A. P., Kim, J. H., Sloan, R. G. (2012). Detecting earnings management: a new approach. Journal of Accounting Research, 50(2), 275-334.

Destri, A. M. L., Picone, P. M., Minà, A. (2012). Bringing strategy back into financial systems of performance measurement: integrating EVA and PBC. Business Systems Review, 1(1),85-120.

Dhole, S., Manchiraju, H., Suk, I. (2016). CEO inside debt and earnings management. Journal of Accounting, Auditing and Finance,31(4),515550 .

Ding, Y., Zhang, H., \& Zhang, J.(2007). Private vs state ownership and earnings management: evidence from Chinese listed companies. Corporate Governance, 15(2),223-238.

Ebrahim, A. (2007). Earnings management and board activity: an additional evidence. Review of Accounting and Finance, 6(1),42-58.

Feng, M., W. Ge, S. Luo., Shevlin, T. (2011). Why do CFOs become involved in material accounting manipulations. Journal of Accounting and Economics ,51,21-36.

García-Meca, E., Sánchez-Ballesta, J. P. (2009). Corporate governance and earnings management: a meta-analysis. Corporate Governance: An International Review, 17(5),594-610.

Gleason, C. A., Pincus, M., Rego, S. O. (2017). Material weaknesses in tax-related internal controls and last chance earnings management. The Journal of The American Taxation Association, 39(1),25-44.

Gras-Gil, E., Manzano, M. P., Fernández, J. H. (2016). Investigating the relationship between corporate social responsibility and earnings management: evidence from Spain. Business Research Quarterly, 19,289-299.

Hajabedi, S., Mousakhani, M., Orooji, A. (2016). Prediction of Economic Value Added status of Tehran Stock Exchanges by using Genetic Algorithm. Bulletin de la Société Royale des Sciences de Liège, 85,1102-1118.

Healy, P. M., Wahlen, J. M. (1999). A review of the earnings management literature and its implications for standard setting. Accounting Horizons, 13(4), 365-383.

Hochberg, Y. V. (2012). Venture capital and corporate governance in the newly public firm. Review of Finance, 16(2),429-480.

Hoglund, H. (2012). Detecting earnings management with neural networks. Expert Systems with Applications, 39,9564-9570.

Hsieh, C. I., Ren, Y., Lirely, R. (2016). Earnings management, executive compensation and layoffs. Academy of Accounting and Financial Studies Journal, 20(3),84-102.

Huang, D. T., Liu, Z. C. (2011). The relationships among governance and earnings management: an empirical study on non-profit hospitals in Taiwan. African Journal of Business Management, 5(14),5468-5476.

Huang, D. T., Liu, Z. C. (2010). Board composition and corporate value in Taiwan high technology firms. The International Journal of Organizational Innovation, 2(4),126-138.

Huang, H-W., Mishra, S., Raghunandan, K. (2007). Types of non audit fees and financial reporting quality. Auditing: A Journal of Practice and Theory, 26(1), 133-145.

Ifada, L. M., Wulandari, N. (2015). The effect of deferred tax and tax planning toward earnings management practice: an empirical study on nonmanufacturing companies listed in Indonesia stock exchange in the period of 2008-2012. International Journal of Organizational Innovation, 8(1), 155-170.

Jones, J. (1991). Earnings management during import relief investigations. Journal of Accounting Research, ,29,1-31.

Lin, F. Y., Wu, S. F. (2014). Comparison of cosmetic earnings management for the developed markets and emerging markets: some empirical evidence from the United States and Taiwan. Economic Modelling, 36,466-473.

Liu, C., Yuen, C. Y., Yao, L. J., Chan, S. H. (2014). Differences in earnings management between firms using US GAAP and IAS/IFRS. Review of Accounting and Finance, 13(2), 134-155.

Liu, Z. J. (2016). Effect of earnings management on economic value added: a cross-country study. South African Journal of Business Management, 47(1), 29-36

Liu, Y., Ning, Y., Davidson III, W. N. (2010). Earnings management surrounding new debt issues. The Financial Review,45, 659-681.

Lin, J. W., Hwang, M. I. (2010). Audit quality, corporate governance, and earnings management: a meta-analysis. International Journal of Auditing, 14, 57-77.

Louis, H. (2004). Earnings management and the market performance of acquiring firms. Journal of Financial Economics, 74,121-148.

Mahmoudi, S., Mahmoudi, S., Mahmoudi A. (2017). Prediction of earnings management by use of multilayer perceptron neural networks with two hidden layers in various industries. Journal of Entrepreneurship, Business and Economics, 5(1), 216-236.

Maitah, M., Saleem, N., Malec, K., Boubaker, M., Gouda, S. (2015). Economic value added and stock market development in Egypt. Asian Social Science, 11(3),126-134. 
Manorselvi, A., Vijayakumar, A. (2007). Performance of Indian automobile industry: economic value added approach. Management and Labour Studies, 32(4),451- 467.

Martani, D., Saputra, Y. E. (2009). The impact of corporate governance to the economic value added listed company in BEI $2003-2004$. China-USA Business Review, 8(3),26-40.

Matsumoto, D. A. (2002). Management's incentives to avoid negative earnings surprises. Accounting Review,77,483-514.

Mitani, H.(2010). Additional evidence on earnings management and corporate governance. FSA Research Review, 6,1-22.

Mizik, N. (2010). The theory and practice of myopic management. Journal of Marketing Research,47,594-611.

Noor, R. M., Mastuki, N., Aziz, Z. (2007). Earnings management and deferred tax. Malaysian Accounting Review, 6(1), 1-17.

Peni, E., Vahamaa, S. (2010). Female executives and earnings management. Managerial Finance, 36(7),629-645.

Phan, H. V., Khieu, H. D., Golec, J. (2017). Does earnings management relieve the negative effects of mandatory pension contributions. Financial Management, spring, 89-128.

Piot, C., Janin, R. (2007). External auditors, audit committees and earnings management in France. European Accounting Review, 16(2),429454.

Pourhasan, R. A. A., Mansour, G. (2014). Comparison of earnings management prediction using neural networks model and modified linear Jones model. Asian Journal of Research in Social Sciences and Humanities, 4(7),456-465.

Roychowdhury, S. (2006). Earnings management through real activities manipulation. Journal of Accounting and Economics, 42(3),335-370.

Saha, A., Ahmad, N. H., Yeok, S. G. (2016). Evaluation of performance of Malaysian banks in risk adjusted return on capital (RAROC) and economic value added (EVA) framework. Asian Academy of Management Journal of Accounting and Finance, 12(1), 25-47.

Shil, N. C., Das, B. (2012). Right product pricing: application of activity-based costing (ABC)-and- economic value added (EVA) as an integrated tool. African Journal of Business Management, 6(44),10826-10833.

Shiri, М. М., Salehi, M., Bahrami, М. (2013). Prediction of economic value added of Iranian listed companies. СОВРЕМЕННАЯ ЭКОНОМИКА: ПРОБЛЕМЫ, ТЕНДЕНЦИИ, ПЕРСПЕКТИВЫ,9,45-55.

Stewart, G. B. (1991). The quest for value. New York: Harperbusiness.

Teker, D., Teker, S., Sönmez, M. (2011). Economic value added performances of publicly owned banks: evidence from Turkey. International Research Journal of Finance and Economics, 75,132-138.

Tsai, C. F., Chiou, Y. J. (2009). Earnings management prediction: a pilot study of combining neural networks and decision trees. Expert Systems with Applications, 36,7183-7191.

Victoria, I. A. O., Kamoche, K. (2016). An assessment of the adoption of economic value added (EVA) as a performance measure in the Kenya insurance industry. International Journal of Finance and Accounting, 1(1),107-124.

Vijaykumar, A. (2010). Economic value added and market value added: an empirical study of relationship. College Sadhana, 2(2),141-148.

Wang, Y. S., Jiang, X., Liu, Z. J., Wang, W. X. (2015). Effect of earnings management on economic value added: a China study. Accounting and Finance Research,4,(3),9-19.

Wang, Y., Wang, Y. (2016). Economic value added, corporation growth and overinvestment-based on state-owned corporations. Modern Economy, 7,1640-1652.

Wu, R. S. (2014). Predicting earnings management: a nonlinear approach. International Review of Economics and Finance, $30,1-25$.

Zang, A. Y. (2011). Evidence on the tradeoff between real manipulation and accrual manipulation. The Accounting Review, 87(2),675-703.

Zhao, X., Wang, T. (2012). Economic value added for performance evaluation: a financial engineering. Systems Engineering Procedia, 5,379387.

Zhou, Z., Wu, C. F. (2016). Consistent analyst expectation error and earnings management: evidence from China. Emerging Markets Finance \& Trade, $52,2128-2148$.

Zhu, T., Lu, M., Shan, Y., Zhang, Y. (2015). Accrual-based and real activity earnings management at the back door: evidence from Chinese reverse mergers. Pacific-Basin Finance Journal,.35(A), 317-339. 